\title{
Liquorice (Glycyrrhiza glabra): Production of instant soluble microcapsules
}

\section{Meyan (Glycyrrhiza glabra): Çözünebilir hazır toz üretimi}

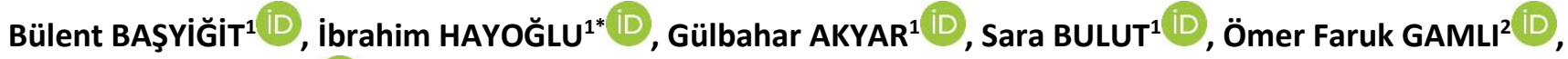 Ahmet Ferit ATASOY ${ }^{1}$}

${ }^{1}$ Harran University, Engineering Faculty, Food Engineering Department, Şanlıurfa, Turkey

${ }^{2}$ Korkut Ata University, Engineering Faculty, Food Engineering Department, Osmaniye, Turkey

\section{To cite this article:}

Başyiğit, B., Hayoğlu, i., Akyar, G., Bulut, S. Gamlı, Ö.F. \& Atasoy, A.F. (2021). Liquorice

(Glycyrrhiza glabra): Production of instant soluble microcapsules. Harran Tarım ve Gıda Bilimleri Dergisi, 25(1): 65-71.

DOI:10.29050/harranziraat.771780

Address for Correspondence: Ibrahim HAYOĞLU

e-mail:

ihayoglu@harran.edu.tr

Received Date:

20.07.2020

Accepted Date:

05.11.2020

(C) Copyright 2018 by Harran University Faculty of Agriculture. Available on-line at www.dergipark.gov.tr/harranziraat

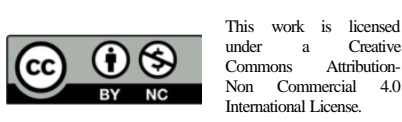

\section{ABSTRACT}

In this study, bioactive compounds were extracted from liquorice (Glycyrrhiza glabra) and converted to instant form by the spray dryer. The four different feed emulsions were prepared with liquorice extract as core material, $12 \%$ maltodextrin (DE 18-20)/gum Arabic (MD/GA) combination as the coating material. The ratio of core to wall was $1: 3$. The MD and GA ratio significantly $(p<0.05)$ affected on some parameters of final products. The encapsulation yield and efficiency were observed to vary between range of $46.30-64.11 \%$ and 98.15-98.62\%, respectively. The encapsulation yield of the feed emulsion of $\mathrm{FE}_{4}$ (MD/GA: 2.25/0.75) was the highest in comparison to the values for other feed emulsions. However, there were not find any significant differences between encapsulation entrapment of the feed emulsions ( $p>0.05)$. The highest total phenolic substances ( $7.02 \mathrm{mg}$ GAE per $\mathrm{g}$ of sample) and antioxidant activity (60.15 mg TEAC per g of sample) were found in $\mathrm{FE}_{1}$ (MD/GA: 0.75/2.25). This study proves the success of instant liquorice production using a spray drying technique.

Key Words: Glycyrrhiza glabra, Powder, Maltodextrin, Gum Arabic, Spray drying

öz

Bu çalışmada meyan kökünden (Glycyrrhiza glabra) biyoaktif bileşikler ekstrakte edilmiş ve elde edilen ekstraktlar püskürtmeli kurutma tekniği ile toz forma dönüştürülmüştür. Kurutma yardım materyali olarak maltodekstrin (MD) ve gam arabikin (GA) farklı konsantrasyonları kullanılmıştır. Çekirdek materyalinin kaplama materyaline oranı 1:3 olarak ayarlanmış ve tüm denemelerde sabit tutulmuştur. Kullanılan duvar materyali konsantrasyonu elde edilen son ürünlerin bazı özellikleri üzerine istatistiksel olarak etki olduğu saptanmıştır $(p<0.05)$. Enkapsülasyon verimi ve enkapsülasyon etkinliği sırasıyla $46.30-64.11 \%$ ve $98.15-98.62 \%$ arasında bulunmuştur. $\mathrm{FE}_{4}$ (MD/GA: 2.25/0.75) emulsiyonunun kapsüllüme verimi diğer emülsiyonlar ile karşılaştırıldığında en yüksek bulunmuştur. Fakat farklı emülsiyonların enkapsülasyon etkinliği üzerine önemli derecede etkileri görülmemiştir ( $p>0.05)$. En yüksek toplam fenolik madde içeriği (7.02 mg GAE/g toz) ve antioksidan aktivite $(60.15 \mathrm{mg} \mathrm{TEAC} / \mathrm{g}$ toz) $\mathrm{FE}_{1}$ (MD/GA: 0.75/2.25) emülsiyonunda bulunmuştur. Bu çalışma, püskürtmeli kurutma tekniği kullanarak hazır meyan kökü üretiminin başarılı bir şekilde gerçekleştirilebileceğini göstermiştir.

Anahtar Kelimeler: Glycyrrhiza glabra, Toz, Maltodekstrin, Gam Arabik, Püskürtmeli kurutma

\section{Introduction}

Liquorice 'Glycyrrhiza glabra' belonging to Fabaceae is grown in tropical and subtropical regions (Vibha et al., 2009). There are more than
30 Glycyrrhiza glabra varieties in the region from the Mediterranean to the east of Europe. The used parts of the plant are roots (Liquiritae radix), and extracts (Liquirritiae succus) obtained from roots. Liquorice has been used as tea in the non- 
alcoholic beverage industry throughout the world. Its extract contains about 500 different useful compounds such as antioxidants, saponin, isoflavone. Therefore, it is consumed widely and also used in the treatment of diseases. Liquorice is evaluated as an enrichment material in different food products and a considerable ingredient of pharmaceutical and cosmetics (Hayoğlu et al., 2017; Tung et al., 2016; Wang et al., 2015).

Liquorice tea is produced by traditional methods and consumed daily. It is served in tea bags containing its root or prepared traditionally and consumed. However, its shelf life is too short. Additionally, it has also a problem that is unpractical like instant coffee. The instant products produced by proper techniques do not exert the aforementioned shortcomings. Spray drying is generally used to produce instant products. It is cheaper than freeze-drying (Moreau and Rosenberg, 1996). Other advantages are low cost, easy handling, preservation of volatile and aroma substances stability (Reineccius, 2004). Previous data regarding the microencapsulation of sour cherry juice (Garofulić et al., 2017) was reported. Similarly, liquorice root extract can be converted to instant form by spray drying technique. Maximum microencapsulation yield (MY), microencapsulation efficiency (ME), and flowing property were determined in emulsion prepared by using $100 \%$ maltodextrin as a wall material in our previous study conducted for finding the optimum ratio of gum Arabic to maltodextrin (Başyiğit and Hayoğlu, 2019). All properties of powders produced at the optimum point were investigated in this previous study. Additionally, the effect of gum Arabic and maltodextrin on all properties of liquorice powder is essential to discuss in detail. Therefore, we used a binary mix (except \%100 maltodextrin) of maltodextrin (DE 18-20) (MD) and gum Arabic (GA) as encapsulating agent for the production of instant liquorice in this study and investigated the changes in Hausner ratio, colour values, water activity, solubility, moisture content, wettability, surface, and total phenolic content and antioxidant activity of final products.

\section{Material and Methods}

\section{Materials and chemicals}

Liquorice was obtained from a local grower in Şanlıurfa province of Turkey. After drying at ambient conditions for 7 days, it was used for further analysis. The coating materials (MD and GA) were obtained from Smart Chemistry (Izmir, Turkey). The remaining chemicals used in the analyses were purchased from Sigma and Merck (Darmstadt, Germany).

\section{Extraction conditions for phenolics}

A $100 \mathrm{ml}$ glass beaker containing 5 gram liquorice and $50 \mathrm{~mL}$ water was incubated at $60^{\circ} \mathrm{C}$ for $60 \mathrm{~min}$. After centrifuging at $5000 \mathrm{rpm}$ for 5 min, the extract was collected and stored at -18 ${ }^{\circ} \mathrm{C}$ for using in the further analysis Başyiğit and Hayoğlu, 2019).

$0.5 \mathrm{~g}$ instant liquorice was mixed with $10 \mathrm{~mL}$ ethanol for surface phenolic analysis (Zhang et al., 2007), $10 \mathrm{ml}$ water for total phenolic analysis (Içyer, 2012). These mixtures were incubated at ambient conditions for $4 \mathrm{~min}$ in a shaker. After centrifuging at $5000 \mathrm{rpm}$ for $5 \mathrm{~min}$, the extract was collected and stored at $-18{ }^{\circ} \mathrm{C}$ for use in further analysis.

\section{Microencapsulation of liquorice extract}

Feed emulsion solid content was adjusted according to total soluble solid content (TSSC) of extract. The total soluble solids content, which

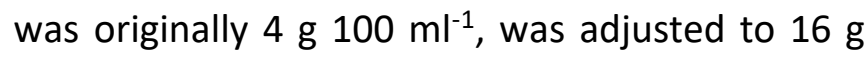
$100 \mathrm{~mL}^{-1}$ by adding MD and GA Başyiğit and Hayoğlu, 2019). The homogenization process was carried out for 5 min by Ultra-Turrax homogenizer (IKA-T18 Basic, Japan). Emulsions were fed as a $100 \mathrm{ml}$ mixture for spray drying. The effects of the $\mathrm{MD} / \mathrm{GA}$ ratio on the quality parameters of instant liquorice microcapsules were investigated. The concentrations of wall material are given in Table 1.

Microencapsulation was applied by a laboratory-type spray dryer (Buchi-B290, Flawil, Switzerland) with a division diameter of $16.5 \mathrm{~cm}$ and a division length of $60 \mathrm{~cm}$. Conditions: air inlet temperature $140{ }^{\circ} \mathrm{C}$, outlet temperature $93 \pm 3{ }^{\circ} \mathrm{C}$, the pump speed $600 \mathrm{I} \mathrm{h}^{-1}$, feeding rate $8 \mathrm{ml} \mathrm{min}^{-1}$. 
Table 1. The wall material concentrations

\begin{tabular}{|l|l|}
\hline Feed Emulsion & $\mathrm{TSSC} / \mathrm{MD} / \mathrm{GA}(\mathrm{g} / \mathrm{g} / \mathrm{g})$ \\
\hline $\mathrm{FE}_{1}$ & $1: 0.75: 2.25$ \\
\hline $\mathrm{FE}_{2}$ & $1: 0: 3$ \\
\hline $\mathrm{FE}_{3}$ & $1: 1.5: 1.5$ \\
\hline $\mathrm{FE}_{4}$ & $1: 2.25: 0.75$ \\
\hline
\end{tabular}

TSSC: Total soluble solid content, MD: Maltodextrin, GA: Gum Arabic

\section{Physiochemical properties of microcapsules}

Microencapsulation yield and efficiency

MY (Çam et al., 2014) and ME (Içyer, 2012) were calculated depending on the following equations (Eq.1 and Eq.2):

$M Y(\%)=\frac{\text { the weight of final products }(g)}{\text { the weight of initial substanses }(g)} \times 100$

$M E(\%)=\left(1-\frac{\text { Phenolics on final products surface }}{\text { Total phenolic of final products }}\right) \times 100$

\section{Moisture and water activity}

The moisture content was performed gravimetrically. The water activity was determined by using the HygroPalm AW1 water activity meter (Rotronic ag, Germany).

\section{Wettability}

The wettability of the products was made in accordance with Turchiuli et al. (2005) by measuring the time to disappear from the water surface using $1 \mathrm{~g}$ sample $\left(100 \mathrm{ml}, 20^{\circ} \mathrm{C}\right)$.

\section{Solubility}

The solubility of products was performed gravimetrically (Cano-Chauca et al., 2005). Boiling distilled water $(50 \mathrm{~mL})$ was mixed with the instant product $(0.5 \mathrm{~g})$. After the mixture was vortexed at ambient conditions, centrifuged at $4000 \mathrm{rpm}$ for 5 min. The supernatant $(25 \mathrm{~mL})$ was added to a petri dish and kept at 70 o $C$ for 24 hours. The following equation was used to determine the solubility (Eq.3).

$$
\text { Solubility }(\%)=\frac{\{[(m 2-m 1) / m 3 \times S 1]}{S 2} \times 100
$$

Where, $\mathrm{m} 1, \mathrm{~m} 2, \mathrm{~m} 3, \mathrm{~s} 1$, and $\mathrm{S} 2$ are the initial weight of the petri dish (g), the final weight of the petri dish (g), the weight of the product $(\mathrm{g})$, the initial amount of water $(\mathrm{mL})$, and the final amount of water added to the petri dish $(\mathrm{mL})$, respectively.
Density

For the bulk and tapped density, $3 \mathrm{~g}$ instant liquorice was put inside the measuring cylinder (25 $\mathrm{mL}$ ) and the cylinder was tapped until reached constant volume on a flat surface. The first volume and second volume were used to determine the bulk and tapped density respectively (Tatar et al., 2014). The bulk and tapped density were determined as $\mathrm{g} / \mathrm{mL}$ by the following equation (Eq.4 and Eq.5):

$$
\begin{aligned}
& \text { Bulk density }(\rho B)=\frac{\text { Products mass }}{\text { Volume of products }} \\
& \text { Tapped density }(\rho T)=\frac{\text { Products mass }}{\text { Final volume of products }}
\end{aligned}
$$

\section{Hausner Ratio}

Hausner ratio (Turchiuli et al., 2005) was calculated by the formula below (Eq.6):

$$
\text { Hausner ratio }(H R)=\frac{\rho T}{\rho B}
$$

Where, $\rho \mathrm{T}$ and $\rho \mathrm{B}$ are the tapped density and the bulk density, respectively.

\section{Surface and total phenolic contents}

Surface and total phenolic content of final products were estimated spectrophotometrically using the Folin-Ciocalteu assay in accordance with Singleton et al. (1999).

ABTS radical scavenging activity of instant liquorice ABTS(2,2'-azino-bis(3-ethyl-benzothiazoline-6sulfonic acid) radical scavenging activity of products was made according to Dai et al. (2010).

\section{Colour analysis}

The colour difference has measured with Colour Quest XE colorimeter (Reston, VA, USA) in accordance with Toğrul and Hayoğlu (2020). The CIE L* (lightness), a* (redness), b* (yellowness), C (chroma), and $h^{\circ}$ (hue angle) values were determined.

\section{Statistical analysis}

Analyses were made in two parallel and three replications. The obtained values were subjected 
to variance analysis (ANOVA) using the SPSS 22.0 package program and evaluated at the significance level of $p<0.05$ according to the Tukey HSD test.

\section{Results and Discussion}

\section{Encapsulation yield}

The $M Y$ is presented in Table 2. The microencapsulation yield of $\mathrm{FE}_{2}, \mathrm{FE}_{1}, \mathrm{FE}_{3}$, and $\mathrm{FE}_{4}$ was 42.30, 56.90, 60.96, and 64.11\%, respectively. All feed emulsion was found more than $50 \%$ except $\mathrm{FE}_{2}$. It is critical that the microencapsulation yield for effective drying is greater than 50\% (Bhandari et al., 1997). The encapsulation yield determined was different than those by reported (Raisin juice) Papadakis et al. (2006), and (Pomegranate juice) Vardin and Yaşar (2012). These authors indicated that there were positive correlations between encapsulation yield and the amount of wall material.

Table 2. Effects of wall concentration on yield, efficiency, moisture content, Hausner ratio, water activity, solubility and wettability of final product

\begin{tabular}{|l|l|l|l|l|l|l|l|}
\hline $\begin{array}{l}\text { Feed } \\
\text { Emulsion }\end{array}$ & $\begin{array}{l}\text { Yield } \\
(\%)\end{array}$ & Efficiency (\%) & $\begin{array}{l}\text { Moisture } \\
\text { content (\%) }\end{array}$ & $\begin{array}{l}\text { Water } \\
\text { activity }\end{array}$ & $\begin{array}{l}\text { Hausner } \\
\text { ratio }\end{array}$ & Solubility (\%) & Wettability (s) \\
\hline $\mathrm{FE}_{1}$ & 56.60 & $98.55 \pm 0.36^{\mathrm{a}}$ & $2.09 \pm 0.01^{\mathrm{a}}$ & $0.21 \pm 0.01^{\mathrm{a}}$ & $1.53 \pm 0.01^{\mathrm{a}}$ & $99.40 \pm 0.01^{\mathrm{b}}$ & $212 \pm 3.54^{\mathrm{a}}$ \\
$\mathrm{FE}_{2}$ & 42.30 & $98.37 \pm 0.03^{\mathrm{a}}$ & $1.47 \pm 0.01^{\mathrm{d}}$ & $0.16 \pm 0.01^{\mathrm{b}}$ & $1.40 \pm 0.01^{\mathrm{d}}$ & $98.69 \pm 0.01^{\mathrm{d}}$ & $234 \pm 10.61^{\mathrm{a}}$ \\
$\mathrm{FE}_{3}$ & 60.96 & $98.30 \pm 0.04^{\mathrm{a}}$ & $1.74 \pm 0.02^{\mathrm{b}}$ & $0.20 \pm 0.01^{\mathrm{a}}$ & $1.50 \pm 0.01^{\mathrm{b}}$ & $99.22 \pm 0.01^{\mathrm{c}}$ & $217 \pm 3.54^{\mathrm{a}}$ \\
$\mathrm{FE}_{4}$ & 64.11 & $98.60 \pm 0.48^{\mathrm{a}}$ & $1.58 \pm 0.01^{\mathrm{c}}$ & $0.17 \pm 0.01^{\mathrm{b}}$ & $1.43 \pm 0.01^{\mathrm{c}}$ & $99.50 \pm 0.01^{\mathrm{a}}$ & $231 \pm 1.41^{\mathrm{a}}$ \\
\hline
\end{tabular}

*The results are expressed as a mean \pm standard deviation of three replicates. Different lowercase letters ( ${ }^{\text {a-d }}$ ) in the same column represent the differences among the means $(p<0.05)$

\section{Moisture content and water activity}

Statistically significant differences $(p<0.05)$ were observed among the moisture content of feed emulsions (Table 2). As expected, there was also a significant difference $(p<0.05)$ among the water activity of final products. The differences could be attributed to the different emulsion viscosity (Premi and Sharma, 2017). When the MD in the emulsion is high, moisture content decreases (Nhu Quynh et al., 2016). The moisture content ranged between 1.47 and $2.09 \%$ which was sufficiently necessary to make food powder microbiologically safe. The moisture content less than $5 \%$ is considered as the criteria for the instant product produced by spray drying. Therefore, the instant liquorice could have a long shelf life as microbiological and chemical degradation are difficult under 0.3 of water activity (Bicudo et al., 2015).

\section{Hausner Ratio}

The parameter plays an important role in the packaging and transport of the product. The lower the Hausner ratio the higher the flowability. The $\mathrm{FE}_{2}$ exhibited the highest flowability, followed by $\mathrm{FE}_{4}>\mathrm{FE}_{3}>\mathrm{FE}_{1}$ (Table 2). All samples showed different flowability (week or too week) because of van der Waals and electrostatic forces core material (Tze et al., 2012).

\section{Solubility and wettability}

Solubility is an indication of the ability to form a solution or suspension in water for spray dried products (Bicudo et al., 2015). The $\mathrm{FE}_{4}$ exhibited higher solubility compared to $\mathrm{FE}_{1}, \mathrm{FE}_{2}$, and $\mathrm{FE}_{3}$. The solubility of products ranged from 98.69 to 99.50\%. The results were more than those by reported Sanchez-Reinoso et al. (2017) while working on spray drying of cocoa aroma.

Wettability is known as the water absorption ability of encapsulated powder (Gaiani et al., 2007). The wettability values varied from 212 to $234 \mathrm{sec}$. The results were in agreement with Fernandes et al. (2013) while working with spray dried rosemary essential oil (155-481 sec).

Antioxidant activity, encapsulation efficiency, surface phenolic content and total phenolic content

Figure 1 shows the antioxidant activity measured by the ABTS method. The antioxidant activities were found to be in following order: $\mathrm{FE}_{1}$ 
(60.15 mg TEAC g $\left.{ }^{-1}\right)>$ FE $_{2}\left(56.54 \mathrm{mg} \mathrm{TEAC} \mathrm{g}^{-1}\right)>$ $\mathrm{FE}_{4}\left(51.48 \mathrm{mg} \mathrm{TEAC} \mathrm{g}^{-1}\right)>\mathrm{FE}_{3}\left(50.13 \mathrm{mg} \mathrm{TEAC} \mathrm{g}^{-1}\right)$. The same order was also observed for the total phenolic content of products (Figure 2). The total phenolic content of products was found to vary between ranges of 6.45-7.02 $\mathrm{mg} \mathrm{GAE} \mathrm{g}^{-1}$. Due to the lack of information in the literature about liquorice encapsulation, we have compared the results with those of other products. Previous studies on total phenolic content and antioxidant activity of different instant products such as pomegranate juice ( $8.80 \mathrm{mg} \mathrm{GAE} \mathrm{g}^{-1}$ ) (Miravet et al. 2016), Mentha spicata (81.12 $\mathrm{mg} \mathrm{GAE} \mathrm{g}^{-1}$ ), and Mentha piperita (69.85 mg GAE g ${ }^{-1}$ ) (Alaşalvar, 2017) and pomegranate juice (6.03 mg TEAC g $\left.{ }^{-1}\right)$ (Miravet et al., 2016) were reported.

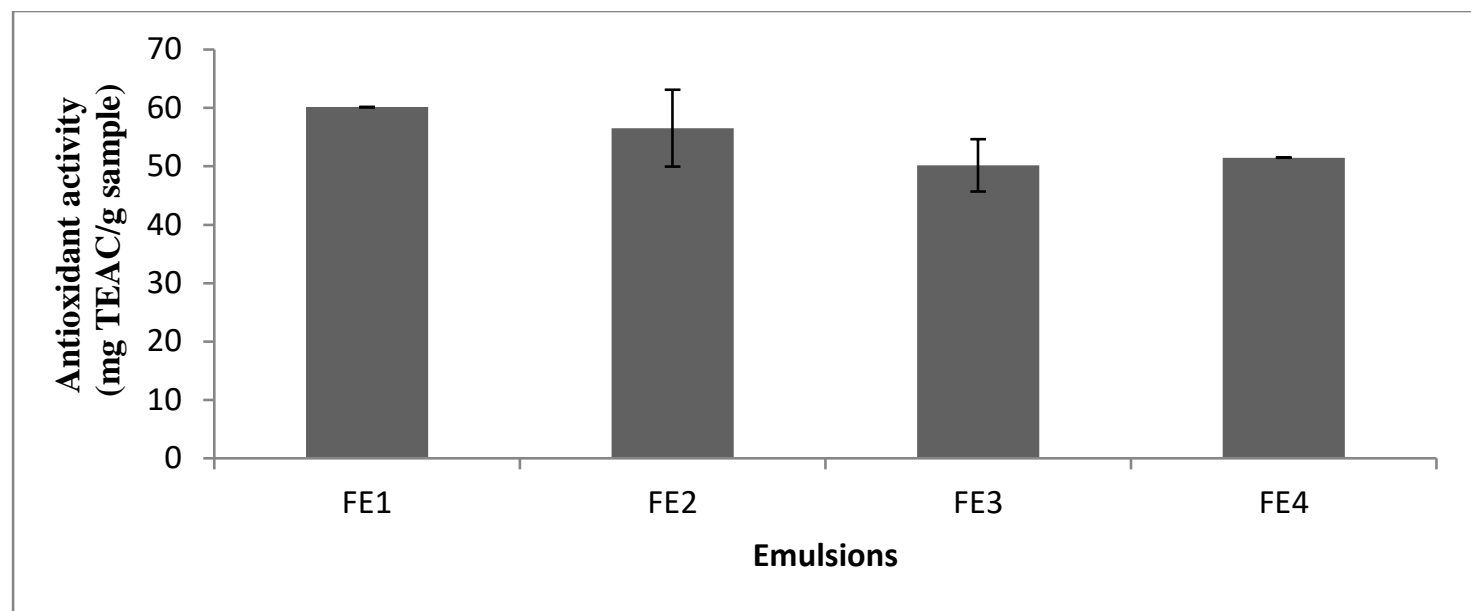

Figure 1. Antioxidant activity of final products

The lower the surface phenolic contents the higher efficiency and the higher stability. Encapsulation efficiency was not significantly $(p>0.05)$ influenced with wall material concentration (Table 2). Because, liquorice contains starch and different gums. The structures behaved like wall material and protected the bioactive compound. These results indicated that the surface phenolic content depends on not only wall material but also core material.

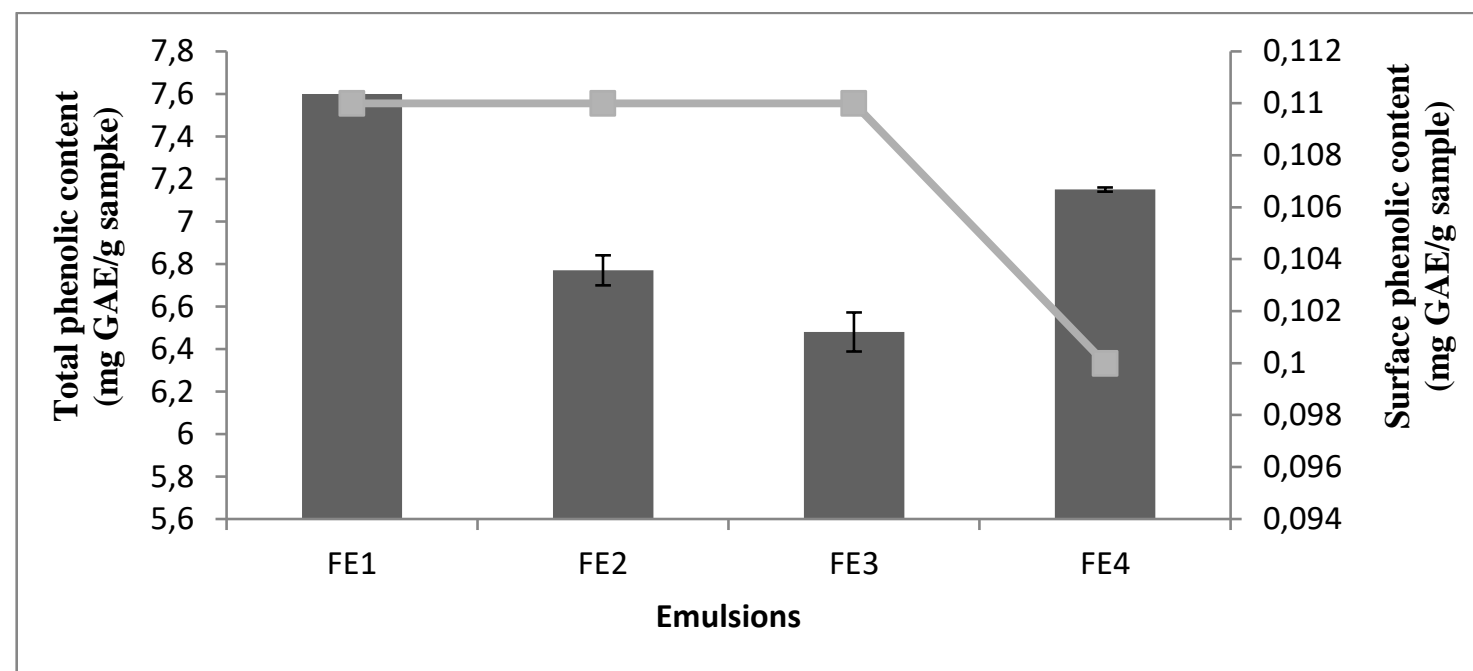

Figure 2. Total phenolic and surface phenolic content of final products GAE: Gallic acid equivalent, TEAC: Trolox equivalent antioxidant activity

\section{Colour}

Lightness values and hue angle (more yellow) of $\mathrm{FE}_{2}$ were significantly higher $(\mathrm{p}<0.05)$ than the other products (Table 3 ). On the other hand, the $\mathrm{FE}_{4}$ had also lower redness ( $\left.a^{*}\right)$. The decrease in
MD concentration leads to a reduction in redness, blueness, and Croma for instant liquorice because of the white color of MD (Kang et al., 2019). The hue angle was higher in $\mathrm{FE}_{2}$ than the others, indicating that $\mathrm{FE}_{2}$ was less red compared to the 
others. Furthermore, the lowest chroma was found for instant products obtained by formulation $\mathrm{FE}_{2}$ with $\mathrm{GA}$ as wall material. The results indicated that the wall material concentration and type were significant $(p<0.05)$ on product colour.

Table 3. Effects of wall concentration on final product colour

\begin{tabular}{|l|l|l|l|l|l|}
\hline Feed Emulsion & $\mathrm{L}^{*}$ & $\mathrm{a}^{*}$ & $\mathrm{~b}^{*}$ & Chroma & Hue angle \\
\hline $\mathrm{FE}_{1}$ & $74.83 \pm 0.01^{\mathrm{b}}$ & $3.11 \pm 0.01^{\mathrm{c}}$ & $26.38 \pm 0.01^{\mathrm{bc}}$ & $26.75 \pm 0.27^{\mathrm{bc}}$ & $83.32 \pm 0.06^{\mathrm{b}}$ \\
$\mathrm{FE}_{2}$ & $75.87 \pm 0.01^{\mathrm{a}}$ & $2.55 \pm 0.49^{\mathrm{d}}$ & $25.15 \pm 0.75^{\mathrm{c}}$ & $25.27 \pm 0.75^{\mathrm{c}}$ & $84.22 \pm 0.06^{\mathrm{a}}$ \\
$\mathrm{FE}_{3}$ & $74.58 \pm 0.14^{\mathrm{b}}$ & $3.26 \pm 0.01^{\mathrm{b}}$ & $27.83 \pm 0.09^{\mathrm{ab}}$ & $28.02 \pm 0.09^{\mathrm{ab}}$ & $83.30 \pm 0.01^{\mathrm{b}}$ \\
$\mathrm{FE}_{4}$ & $73.28 \pm 1.20^{\mathrm{c}}$ & $3.48 \pm 0.01^{\mathrm{a}}$ & $28.91 \pm 0.01^{\mathrm{a}}$ & $29.55 \pm 0.61^{\mathrm{a}}$ & $83.03 \pm 0.15^{\mathrm{b}}$ \\
\hline
\end{tabular}

*The results are expressed as a mean \pm standard deviation of three replicates. Different lowercase letters ( $\left.{ }^{\text {a-d }}\right)$ in the same column represent the differences among the means $(p<0.05)$

\section{Conclusion}

Liquorice extract has short shelf life resulting from a high microbial load and preparing its extract is not practical. However, instant liquorice showed that low moisture content (1.47-2.09\%) and water activity (below 0.3 ). Therefore, the products were microbiologically safe range. Preparation of instant liquorice such as instant coffee, tea is not taken time. Furthermore, instant liquorice can be produced using MD and GA. On the other hand, it could be produced by using different wall materials except for $M D$ and $G A$ and in the different spray drying conditions in future studies.

\section{Acknowledgements}

This work was financially supported by Harran University Scientific Research Projects Unit (Project Number: HUBAP- 17042).

Conflict of Interest: The authors declare no conflict of interest.

Author Contribution: Bülent BAŞYiĞiT: Formal analysis, Conceptualization, Data curation, Investigation, Methodology, Software, Writingoriginal draft. ibrahim HAYOĞLU: Conceptualization, Data curation, Investigation, Project administration, Resources, Supervision, Writing - original draft, Writing- review \& editing. Gülbahar AKYAR: Formal analysis, Investigation, Methodology. Sara BULUT: Formal analysis, Investigation, Methodology. Ömer Faruk GAMLI: Visualization, Writing - original draft. Ahmet Ferit ATASOY: Software, Writing - original draft.

\section{References}

Alaşalvar, H. (2017): Production of iced tea from medical and aromatic mint species. MSc thesis (in Turkish), Turkey: Erciyes University.

Basyigit, B., \& Hayoglu, I. (2019). Liquorice (Glycyrrhiza glabra L.) root sherbet (extract): Microencapsulation and storage stability. Acta Alimentaria, 48(1), 76-85.

Bhandari, B. R., Datta, N., Crooks, R., Howes, T., \& Rigby, S. (1997). A Semi-Empirical approach to optimize the quantity of drying aids required to spray dry sugarrich foods. Drying Technology, 15(10), 2509-2525.

Bicudo, M. O. P., Jó, J., Oliveira, G. A. D., Chaimsohn, F .P., Sierakowski, M. R., Freitas, R. A. D., \& Ribani, R. H. (2015). Microencapsulation of juçara (Euterpe edulis M.) pulp by spray drying using different carriers and drying temperatures. Drying Technology, 33(2), 153161.

Çam, M., Hişil, Y., \& Durmaz, G. (2009). Classification of eight pomegranate juices based on antioxidant capacity measured by four methods. Food Chemistry, 112(3), 721-726.

Çam, M., Içyer, N.C., \& Erdoğan, F. (2014). Pomegranate peel phenolics: microencapsulation, storage stability and potential ingredient for functional food development. LWT-Food Science and Technology, 55(1), 117-123.

Cano-Chauca, M., Stringheta, P. C., Ramos, A. M., Cal-Vidal, J. (2005). Effect of carriers on the microstructure of mango powder obtained by spray drying and its functional characterization. Innovative Food Science and Emerging Technologies, 6, 420-428.

Dai, J., Orsat, V., Vijaya Raghavan, G. S., \& Yaylayan, V. (2010). Investigation of various factors for the extraction of peppermint (Mentha piperita L.) leaves. Journal of Food Engineering, 96(4), 540-543.

Fernandes, R. V. D. B., Borges S.V., \& Botrel D.A. (2013). Influence of spray drying operating conditions on microencapsulated rosemary essential oil properties. Food Science and Technology International (Campinas), 33, 171-178.

Gaiani, C., Scher, J., Ehrhardt, J.J., Linder, M., Schuck, P., Desobry, S., \& Banon, S. (2007). Relationships between Dairy Powder surface composition and wetting properties during storage: importance of residual lipids. Journal of Agricultural and Food Chemistry, 55(16), 6561-6567. 
Garofulić, I.E., Zorić, Z., Pedisić, S., \& Dragović-Uzelac, V. (2017). Retention of Polyphenols in encapsulated sour cherry juice in dependence of drying temperature and wall material. LWT-Food Science and Technology, 83, 110-117.

Hayoğlu, İ., Çelik, Ş., Türkoğlu, H., Başyiğit, B., \& Ünver, N. (2017). Effects of licorice on some selected properties of ice cream. Hacettepe Journal of Biology and Chemistry, 45(3), 365-370.

Icyer, N.C. (2012). Extraction of pomegranate peel phenolics with water and microencapsulation of the extracts. MSc thesis (in Turkish), Turkey: Erciyes University.

Kang, Y. R., Lee, Y. K., Kim, Y. J., \& Chang, Y. H. (2019). Characterization and storage stability of chlorophylls microencapsulated in different combination of gum Arabic and maltodextrin. Food Chemistry, 272, 337346.

Miravet, G., Alacid, M., Obón, J. M., \& Fernández-López, J. A. (2016). Spray-drying of pomegranate juice with prebiotic dietary fibre. International Journal of Food Science \& Technology, 51(3), 633-640.

Moreau, D. L., \& Rosenberg M. (1996). Oxidative stability of anhydrous microencapsulated whey proteins. Journal of Food Science, 61, 39-43.

Nhu Quynh, N. T., Hai, T. C., Man, P. V., \& Thanh, L. T. (2016). Effect of wall material on the property of Gac oil spray-dried power. Journal of Nutrition \& Food Sciences, 6, 1-4.

Papadakis, S. E., Gardeli, C., \& Tzia, C. (2006). Spray drying of raisin juice concentrate. Drying Technology, 24(2), 173-180.

Premi, M., \& Sharma, H. K. (2017). Effect of different combinations of maltodextrin, gum arabic and whey protein concentrate on the encapsulation behavior and oxidative stability of spray dried drumstick (Moringa oleifera) oil. International journal of biological macromolecules, 105, 1232-1240.

Re, R., Pellegrini, N., Proteggente, A., Pannala, A., Yang, M., \& Rice-Evans, C. (1999). Antioxidant activity applying an improved ABTS radical cation decolonization assay. Free Radical Biology and Medicine, 26(9-10), 1231-1237.

Reineccius, G. A. (2004). The spray drying of food flavors. Drying Technology, 22, 1289-1324.

Sanchez-Reinoso Z., Osorio C., \& Herrera A. (2017). Effect of microencapsulation by spray drying on cocoa aroma compounds and physicochemical characterization of microencapsulates. Powder Technology, 318, 110-
119.

Singleton, V. L., Orthofer, R., \& Lamuela-Raventós, R. M. (1999). Analysis of total phenols and other oxidation substrates and antioxidants by means of FolinCiocalteu reagent. Methods in Enzymology, 299, 152178.

Tatar, F., Tunç, M. T., Dervisoglu, M., Cekmecelioglu, D., \& Kahyaoglu, T. (2014). Evaluation of hemicellulose as a coating material with gum Arabic for food microencapsulation. Food Research International, 57, 168-175.

Toğrul, Ö. \& Hayoğlu, i̇. (2020). Yeni bir izotonik içecek olarak; nar, kızılcık ve karadut suları ile zenginleştirilmiş elma suyu üretim olanakları. Harran Tarım ve Gıda Bilimleri Dergisi, 24 (2), 165-173.

Tung, N. H., Tanaka, H., Tsujimura, A., Miyagawa, Y., \& Wada, M. (2016). In vitro fertilization with mouse sperm activated by components of licorice root extract. Natural Products Chemistry and Research, 4 (217): 2.

Turchiuli, C., Fuchs, M., Bohin, M., Cuvelier, E., Ordonnaud, C., Peyrat-Maillard, M. N., \& Dumoulin, E. (2005). Oil encapsulation by spray drying and fluidised bed agglomeration. Innovative Food Science and Emerging Technologies, 6, 29-35.

Tze, N. L., Han, C. P., Yusof, Y. A., Ling, C. N., Talib, R. A., Taip, F. S., \& Aziz, M. G. (2012). Physicochemical and nutritional properties of spray-dried pitaya fruit powder as natural colorant. Food Science and Biotechnology, 21(3): 675-682.

Vardin, H., \& Yasar, M. (2012): Optimization of pomegranate (Punica granatum L.) juice spray drying as affected by temperature and maltodextrin content. LWT-Food Science and Technology, 47(1), 167-176.

Vibha, J. B., Choudhary Singh, K. M., Rathore, M. S., \& Shekhawat, N. S. (2009). Study on pharmacokinetics and therapeutic efficacy of Glycyrrhiza glabra: a miracle medicinal herb. Botany Research International, 2(3): 157-63.

Wang, L., Yang, R., Yuan, B., Liu, Y., \& Liu, C. (2015). The antiviral and antimicrobial activities of licorice, a widely-used Chinese herb. Acta Pharmaceutica Sinica $B, 5(4), 310-315$.

Zhang, L., Mou, D., \& Du, Y. J. (2007). Procyanidins: extraction and microencapsulation. Journal of the Science of Food and Agriculture, 87, 2192-2197. 